\title{
... And What About those who Disagree with the Measures Against the Pandemic?
}

\author{
Fereniki Panagopoulou* \\ Assistant Professor, Panteion University PhD (Humboldt), LL.M. (National Kapodistrian University of Athens), M.P.H. (Harvard),
} Greece

*Corresponding author: Fereniki Panagopoulou, Assistant Professor, Panteion University PhD (Humboldt), LL.M. (National

Kapodistrian University of Athens), M.P.H. (Harvard), Greece

\begin{tabular}{|c|c|}
\hline ARTICLE INFO & ABSTRACT \\
\hline Received: 仹 December 20, 2021 & $\begin{array}{l}\text { Citation: Fereniki Panagopoulou. ... And What About those who Disagree with } \\
\text { the Measures Against the Pandemic?. Biomed J Sci \& Tech Res 41(1)-2022. BJSTR. }\end{array}$ \\
\hline Published: January 12, 2022 & MS.ID.006536. \\
\hline
\end{tabular}

\section{Opinion}

In recent months a lively debate is taking place on the effectiveness of the various measures taken by national governments to contain the pandemic. Many have raised questions on the possible side effects of the use of masks in public places, especially in schools, of the side effects of vaccination, and so on. Groups of our fellow citizens are protesting about the extended use of masks and the compulsory nature of vaccination, for example, voicing their opinions in numerous ways. Others are going a step further, urging people towards adopting a stance akin to a (supposed) type of civil disobedience [1]. This category includes some parents who, especially on social networking sites, urge other parents not to send their children to school wearing a mask, vaccinated or having conducted a rapid test. The legitimate question that arises is whether the relevant dialogue and action are subject to certain constitutional limits. One of the fundamental pillars of democracy is that relating to freedom of opinion. Freedom of opinion is intertwined with the right to criticize government action. This criticism can go as far as the ordinary citizen questioning government policy measures. When pandemic issues are raised by journalists in the press, however, it is crucial to ensure the accuracy of the information and to limit fake news. Everyone is free to express his or her opinion, but one must also draw a clear distinction between value judgments and facts. The creation of a climate of misinformation and panic by the media is not in keeping with the social mission of the media,

and is likely to cause further problems both for the individual and for society as a whole.

This is even more so the case at this time of extreme difficulty for the population as a whole, when citizens, in a state of restraint and amidst widespread and entirely justified fear of the virus spreading, are regularly informed of developments. Nevertheless, in addition to expressing opinions, many are also taking action inciting civil disobedience. This phenomenon is not unknown: it is an expression of the timeless conflict between natural and statute law. It goes back to antiquity, when Prometheus violated Zeus' command not to reveal the use of fire to humans. Indeed, Sophocles's Antigone is the most brilliant example of civil disobedience, as she refuses to comply with King Creon's order not to bury her brother, Polynices, putting forward her obligation to obey what she considers to be a superior legal system. On the other hand, in Plato's Crito, Socrates emerges as the father of 'civil obedience', as he offers us a prime example of obedience to an unjust, but lawful, sentence [2]. Thoreau is considered by most to be the father of civil disobedience, being the person who introduced the term itself. Back in the mid-19th century he refused to pay taxes and was imprisoned, not because he opposed taxation in general, but because he opposed the US government's war against Mexico, slavery and the violation of Indian rights [3]. The real father of civil disobedience, however, is John Locke, who pointed out that the existence of arbitrary 
authority is a prerequisite for disobedience. In this context, he recognized from 1688 the right of Greek Christians to throw off the Turkish yoke imposed on them by force [4].

In this light, the question arises as to whether one has the right not to wear a mask, not to be vaccinated and also to encourage other people to do so, too. Kant could provide us with the answer: according to him, the legal order in a democratic society is a value in itself. "There can be no justified resistance on the part of the people against the legislative authority of the state. A state governed by the rule of law is only strong when there exists universal subordination to its legislative will [...]. The reason why it is the duty of people to tolerate even what is apparently the most intolerable misuse of supreme power is that it is impossible even to conceive of their resistance to the supreme legislation as being anything other than unlawful and liable to nullify the entire legal constitution".' [5]. It is clearly contradictory, according to Kant, for a legal order to provide the ability to resist its mandates, as this essentially self-negates its supreme authority. This reasoning is only founded when the legal order in question has democratic legitimacy [6]. In a tyrannical regime, where citizens are excluded from the legislative process, there is no issue of obligation of obedience to a heteronomous legal order, and each individual has a right to resist, as well as a right to revolt against it [6]. In a democratic regime, on the other hand, one may express discontent and voice views openly, but has no right not to obey, particularly when the law concerns a fundamental right pertaining to public health. In actual fact, this is not at all an issue of conflict between natural and statute law.

Not complying with rules on hygiene is not related to natural laws. Mask and vaccine deniers are not in agreement with a certain legislative provision, which is based on research data. Let it not be lost on us that, by the same token, they could disagree with the use of masks by doctors in the operating room, the use of gloves by bakers during a pandemic, the use of protective equipment for visitor admission to an intensive care unit, and so on. Such deniers do not argue that wearing a mask and vaccination constitute discrimination against lower social strata - they are essentially projecting a disagreement they have vis-à-vis a particular scientific finding. In the case at hand, and to begin with, scientists ought to make a convincing case to people, based on substantiated arguments. Nevertheless, if a person decides not to wear a mask and does not get vaccinated, without having a medical reason for doing so, then it is wholly reasonable that he or she should be the recipient of the lawful ramifications of the prohibition of entry to the specified area. Therefore, a pupil will be justly denied entry to a classroom, as will a customer to an indoor cinema theatre, a citizen to a public service, to a shop and, even more to the point, to a hospital. Indeed, this is the case as the person in question is unable to support this based on scientific disagreement. Furthermore, if a person is inciting the public to collective disobedience against the use of masks and vaccination, it would be reasonable that he or she should face relevant legal consequences. At this point, it should not be overlooked that any battle of arguments does not place in a vacuum but in the context of a reality which, if ignored, may lead us to very unpleasant surprises [7]. The defiant violation of the use of masks and vaccination is not, at the end of the day, an act of civil disobedience, but rather a manifestation of anti-social autonomy [8].

For the above to become more intelligible, the following conclusions may be drawn:

a) The position "I consider the use of the mask and the enforcement of vaccination in public places problematic: people will not comply and, therefore, this will create more problems" is a constitutionally permissible expression of opinion.

b) The position "I find the use of masks and the imposition of vaccination to be unconstitutional measures" is also a constitutionally permissible expression of opinion.

c) The position of "Don't wear a mask and don't get vaccinated" constitutes incitement to disobedience against a specific provision of the law which - especially in the period of the pandemic - goes beyond the permissible limits of freedom of speech.

d) The non-use of masks and the refusal to get vaccinated during a pandemic, where this is required by law, does not constitute civil disobedience in the sense of what has been set out above: it represents illegal and, mainly, anti-social behavior.

\section{References}

1. Civil disobedience consists in the ability of citizens to disobey the dictates of the political power, relying on political arguments in order to change legislation, institutions or the form of power in place itself. The decisive factor justifying this stance is the loss of legitimacy of power. Cf. George N. Politis (2012), The right to civil disobedience, Psychogios Publications, Athens, p. 12.

2. Stavros Tsakyrakis (2012), Civil disobedience, Lifo, available at: https:// www.lifo.gr/team/readersdigest/33981.

3. David-Henry Thoreau (2008), Civil Disobedience, trans. Constantina Papapetropoulou, ed. Charalambos Magoulas, Erato Publications, Athens.

4. John Locke (1997), in Peter Laslett, (ed) John Locke, Two Treatises of Government, Cambridge (1960): 192.

5. Immanuel Kant (1970), The Metaphysics of Morals, in Political Writings, Cambridge, p. 144.

6. Stavros Tsakyrakis (2012), Civil disobedience, Lifo, available at: https:// www.lifo.gr/team/readersdigest/33981.

7. Panagiotis Doudonis (2020), They play dangerously with our lives, don't let them, Protagon, available at: https://www.protagon.gr/apopseis/paizoun-epikindyna-me-tis-zwes-mas-min-tousafinoume-44342105059.

8. George N. Politis (2012), The right to civil disobedience, Psychogios Publications, Athens, p. 39. 
ISSN: 2574-1241

DOI: 10.26717/BJSTR.2022.41.006536

Fereniki Panagopoulou. Biomed J Sci \& Tech Res

(c) (P) This work is licensed under Creative

Submission Link: https://biomedres.us/submit-manuscript.php

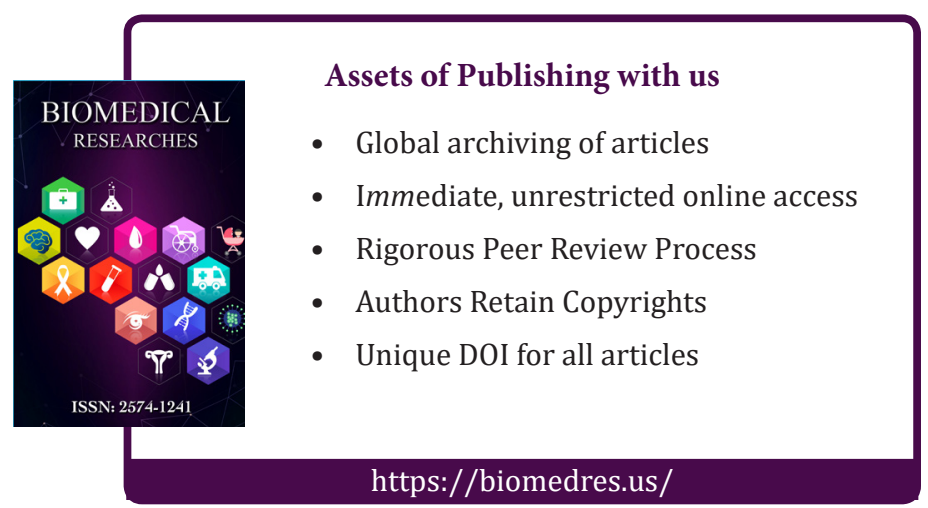

